\title{
Langerhans cell sarcoma with an aberrant cytoplasmic CD3 expression
}

\author{
Zhaodong $\mathrm{Xu}^{1 *}$, Ruth Padmore ${ }^{1}$, Carolyn Faught ${ }^{2}$, Lisa Duffet ${ }^{2}$ and Bruce F Burns ${ }^{3}$
}

\begin{abstract}
Langerhans cell sarcoma is a rare and aggressive high grade hematopoietic neoplasm with a dismal prognosis. It has a unique morphological and immunotypic profile with a CD1a/ langerin/S100 + phenotype. T cell lineage markers except for CD4 in Langerhans cell sarcoma have not been documented previously. We report a case of 86 year-old male of Caucasian descent who presented with an enlarging right neck mass over 2 months with an underlying unknown cause of anemia. Computed tomography scan of the neck, chest and abdomen revealed generalized lymphadenopathy and mild splenomegaly suspicious for lymphoma. Diagnostic core biopsy performed on right neck mass revealed a possible T cell lymphoma with expression of T cell lineage specific marker CD3 but conclusive diagnosis could not be made due to insufficient core biopsy sample. Further excisional biopsy performed on a left inguinal node showed a hematopoietic neoplasm with features of Langerhans cell sarcoma with a focal cytoplasmic CD3 expression in 30-40\% of the tumor cells. PCR for T cell receptor (TCR) gene rearrangement failed to demonstrate a clonal gene rearrangement in the tumor cells arguing against a $T$ cell lineage transdifferentiation, suggesting an aberrant CD3 expression. To the best of our knowledge, this case represents the first report of Langerhans cell sarcoma with an aberrant cytoplasmic CD3 expression.
\end{abstract}

Virtual slides: http://www.diagnosticpathology.diagnomx.eu/vs/2065486371761991

Keywords: Langerhans cell sarcoma (LCS), Langerhans cell histiocytosis $(\mathrm{LCH}), \mathrm{CD}$, Aberrant expression, Lineage plasticity, Transdifferentiation

\section{Background}

According to the most recent WHO Classification of Tumors of Hematopoietic and Lymphoid Tissues (2008) [1], Langerhans cell sarcoma (LCS) belongs to the category of histiocytic and dendritic cell neoplasms. It is a rare subtype of tumors derived from Langerhans cells with a female predominance.

Clinically, LCS is often an extranodal tumor with skin and bone involvement, but it may present with multiorgan involvement including lymph node, lung, liver and spleen. $11 \%$ of the reported cases patients had pancytopenia. Compared to more commonly known Langerhans cell histiocytosis ( $\mathrm{LCH})$, also a clonal neoplastic proliferation of Langerhans cells, LCS has a much higher degree of cytological atypia and prominent proliferation rate with an aggressive clinical course. Both LCH and LCS have a similar immunophenotype including CD1a/

\footnotetext{
* Correspondence: zhaodong_xu@hotmail.com

'Department of Pathology and Laboratory Medicine, Division of Hematopathology, The Ottawa Hospital, 501 Smyth Road, Ottawa, Ontario, Canada

Full list of author information is available at the end of the article
}

langerin/S100+ $[2,3]$ but without B- and T-cell lineage markers except for CD4 [4]. LCS with a cytoplasmic T cell specific marker CD3 has heretofore not been reported in the English literature. Herein we provide the first report of LCS with an aberrant cytoplasmic CD3 expression.

\section{Case presentation}

An 86 year old Caucasian male who had been relatively healthy with medically controlled diabetes on insulin, treated temporal arteritis and myocardial infarction in 1987 without ongoing angina was referred to hematology/Oncology service for possible T cell lymphoma at Ottawa Hospital in July 2011. The patient had a short history of a rapidly growing right neck mass, an anemia of unknown cause, mild weight loss and generalized weakness. Laboratory investigations showed a bicytopenia with a normocytic anemia, Hb $89 \mathrm{~g} / \mathrm{L}$ (reference interval 115-155 g/L) and thrombocytopenia, PLT $86 \mathrm{x}$ $10^{9} / \mathrm{L}$ (reference interval $125-400 \times 10^{9} / \mathrm{L}$ ). He also had a neutrophilia with WBC $19.8 \times 10^{9} / \mathrm{L}$ (reference interval
C Biomed Central

(c) 2012 Xu et al.; licensee BioMed Central Ltd. This is an Open Access article distributed under the terms of the Creative Commons Attribution License (http://creativecommons.org/licenses/by/2.0), which permits unrestricted use, distribution, and reproduction in any medium, provided the original work is properly cited. 
3.0-10.5 $\left.\times 10^{9} / \mathrm{L}\right)$. LDH was mildly elevated with a value of $240 \mathrm{u} / \mathrm{L}($ reference interval 100-205 u/L). CT of neck/ thorax/abdomen demonstrated diffuse lymphadenopathy involving the neck, mediastinum, lung, abdomen and pelvic and mild splenomegaly. Two previous right neck core biopsies at another hospital suggested a peripheral $\mathrm{T}$ cell lymphoma based on the expression of $\mathrm{T}$ cell specific marker CD3 with negative CD20 and cytokeratin AE1/3. Definitive diagnosis could not be made due to insufficient tissue. An excisional left inguinal node biopsy was performed at the Ottawa Hospital.

Microscopic evaluation of formalin-fixed, paraffinembedded lymph node tissue revealed diffuse architectural effacement of the lymph node with replacement by a population of large hematolymphoid cells with very distinctive nuclear features. The nuclei were slightly elongated and many of them showed prominent longitudinal nuclear grooves reminiscent of Langerhans cells (Figure 1 A).
These cells however were larger, had more prominent nucleoli, abundant eosinophilic cytoplasm and a higher degree of pleomorphism than normal Langerhans cells and occasional cells were multinucleated. The cells were growing in sheets and there were very few admixed lymphocytes or eosinophils in the background. Scattered mitotic figures were easily appreciated. (Figure $1 \mathrm{~B}$ ).

The immunohistochemical profile of the case is summarized in Table 1. The tumor cells showed intense membrane staining for CD1a, strong granular cytoplasmic staining for langerin (CD207), strong staining for S100 and CD4. (Figure 1 C, D, E, F). The Ki-67 proliferation index in tumors cells was $>50 \%$ (Figure 1G). p53, a cell cycle regulator (Figure $1 \mathrm{H}$ ) and bcl-2 were also positive. CD30 was focally positive in about $30-40 \%$ of the tumor cells (see Table 1).

Interestingly, specific monoclonal antibody CD3 against epsilon chain of human CD3 complex (LN10,
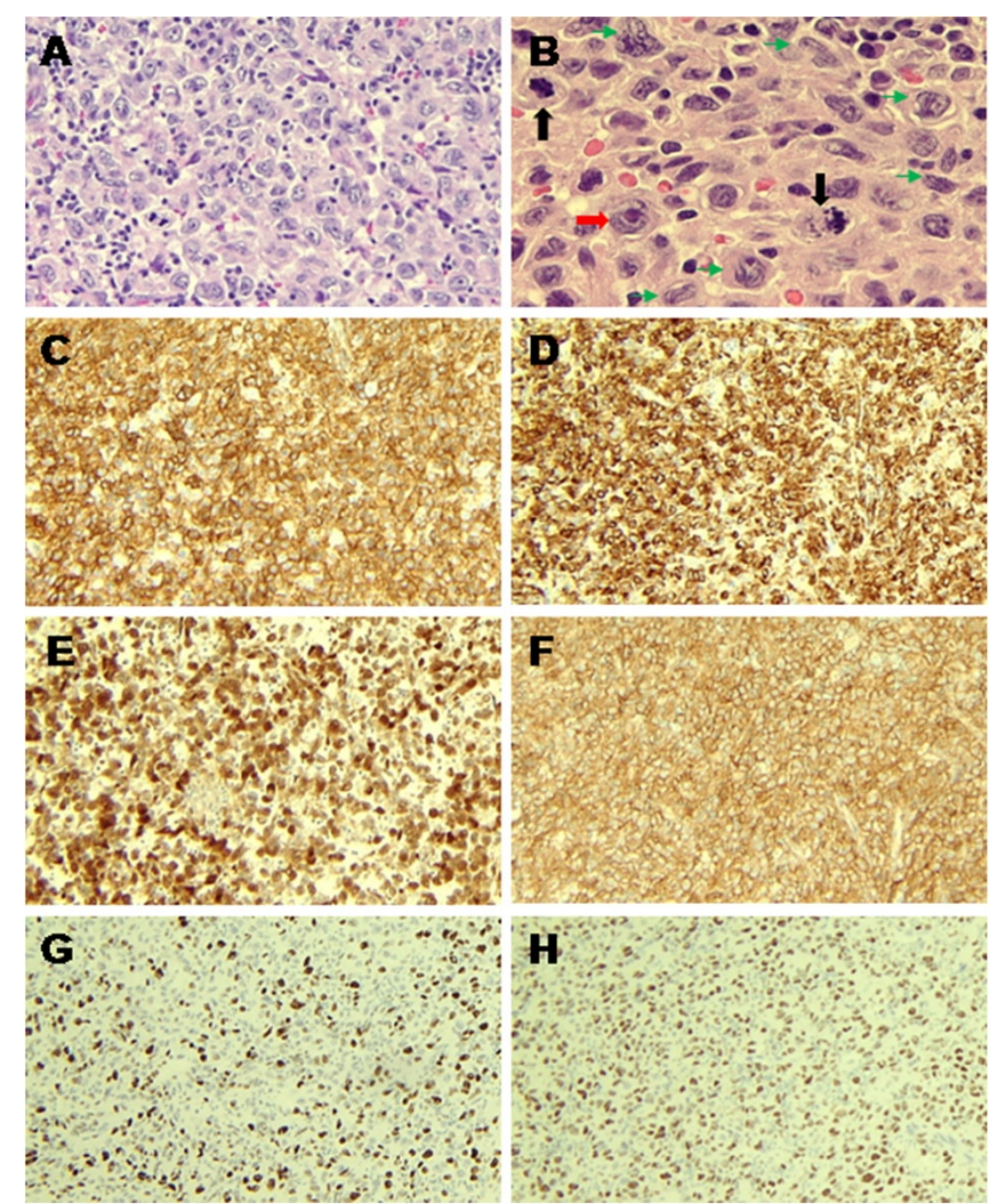

Figure 1 H \& E staining. A. Intermediate power view showing lymph node was replaced by a population of large cells with scattered background small lymphocytes. B. High power views of tumor cells demonstrated typical nuclear groove (green arrows), prominent nucleoli (red arrow), and abundant eosinophilic cytoplasm. Mitotic figures can be easily found (black arrows). Immunohistochemistry. C-H. Tumor cells demonstrated strong positivity for CD1a (C), langerin (D), S100 (E) and CD4 (F). Tumor cells showed positivity for cell cycle regulator p53 (G). Tumor cells were labeled more than $50 \%$ of cell proliferation index marker Ki-67 (H). 
Table 1 Immunohistochemical staining of Langerhans cell sarcoma

\begin{tabular}{lcc}
\hline Marker & $\begin{array}{c}\text { Langerhans cell } \\
\text { sarcoma in our case }\end{array}$ & $\begin{array}{c}\text { Typical immunophenotype } \\
\text { of tumors derived } \\
\text { from Langerhans cells }\end{array}$ \\
\hline CD1a & + & + \\
Langerin & + & + \\
S100 & + & + \\
CD4 & + & + \\
CD3 & $30-40 \%+$ cytoplasm & - \\
p53 & + & $+/-$ \\
CD30 & $30-40 \%+$ & NK \\
BCL2 & + & + \\
Ki-67 & $>50 \%$ & $0-25 \%$ \\
CD5 & - & - \\
CD8 & - & - \\
CD10 & - & - \\
CD20 & - & - \\
CD23 & - & - \\
CD56 & - & - \\
BCL6 & - & - \\
MUM-1 & - & - \\
Cyclin D1 & - & - \\
CD68 & - & - \\
CD163 & - & - \\
ALK & - & - \\
\hline & - & - \\
\hline
\end{tabular}

NK: not known.

Catalog No: PA0553, Leica Biosystems) showed a focal cytoplasmic staining in $30-40 \%$ of the tumor cells, comparing to the strong staining of admixed normal $\mathrm{T}$ lymphocytes (Figure 2 A, B). The morphology and immunohistochemical profile of this tumor strongly suggested a Langerhans cell derived neoplasm. Although double staining immunohistochemistry was not performed, with the extensive degree of staining with CD1a, S100, langerin, CD3 and CD30, the tumor cells were interpreted as positive for all these markers (see Figure 1 and Table 1). The high mitotic rate and high labelling with Ki-67, along with p53 expression, coupled with the significant cytological atypia, rare background eosinophils indicated a diagnosis of Langerhans cell sarcoma. Flow cytometry profiling of the lymph node showed 2 population of cells, a small cell population in the lymphocyte gate showing no abnormal expression of aberrant B and T cell markers, and an abnormal cell population evidenced by a high side scatter in flow histogram, which demonstrated CD4 expression (Figure $2 \mathrm{C}, \mathrm{D}$ ). This was compatible with immunohistochemical findings of CD4 positivity of tumor cells and scatter normal lymphocytes at the background in the tissue block. Cytoplasmic CD3 was not done on flow cytometry but the abnormal cells were negative for surface membrane CD3. Bone marrow aspiration and biopsy did not show bone marrow involvement. Therapy for LCS may be toxic and anti-CD30 therapy (SGN-30) may have modest clinical activity [5,6]; based on the aggressiveness of the disease, patient's age, and poor ECOG performance status [7] with a score 3-4 out of 5, palliative measures with local radiotherapy were instituted after discussion with the patient and his family. Patient died one month later after pathological diagnosis.

\section{Discussion}

Langerhans cells are one subset of hematopoietic cells, thought to derive from monocyte-macrophage lineage. They are specialized dendritic cells in skin or mucosal sites devoted to antigen presentation to $\mathrm{T}$ cells upon activation. They are then thought to migrate to lymph node through lymphatics. Physiologically, Langerhans cells can respond in a non-clonal fashion to certain reactive stimuli such as smoking, in the lung [8,9]. Alternatively, they can proliferate in a clonal pattern, forming tumors designated as $\mathrm{LCH}$ and much less commonly as LCS. LCH can also be associated with other disease processes such as malignant lymphoma, and myasthenia gravis $[10,11]$, but there is still debate about whether these represent a clonal or non-clonal reactive process in those situations.

LCH and LCS have been believed to originate from myeloid stem cells [12-16] rather than lymphoid stem cells, but some recent experimental and clinical evidence has argued against this belief $[17,18]$. Furthermore, some clinical reports have suggested that both B- and T-cell neoplasms can transdifferentiate into LCH and LCS after prolonged treatment of the original disorders [19-23], suggesting that in these hematolymphoid neoplasms the tumor cells have some potential for lineage plasticity, somewhat comparable to the leukemias with lineage plasticity, acute leukemias of ambiguous lineage in the 2008 WHO hematolymphoid tumour classication. Because of its linkage to the T-cell receptor molecules surface membrane CD3 is felt to be the most specific $\mathrm{T}$ lineage marker along with cytoplasmic epsilon chain, although CD3 epsilon chain can be expressed in cytoplasm of NK cells and thymocytes. Furthermore aberrant CD3 expression has been reported in other hemotopoietic tumours such as diffuse large B cell lymphoma, primary mediastinal large B cell lymphoma, plasmablastic lymphoma and classical Hodgkin's lymphoma [24-27] but not in histiocytic sarcoma. In addition, $\mathrm{LCH}$ can co-exist with $\mathrm{T}$ cell lymphoblastic lymphoma in the same tissue, making the correct diagnosis difficult $[28,29]$. 

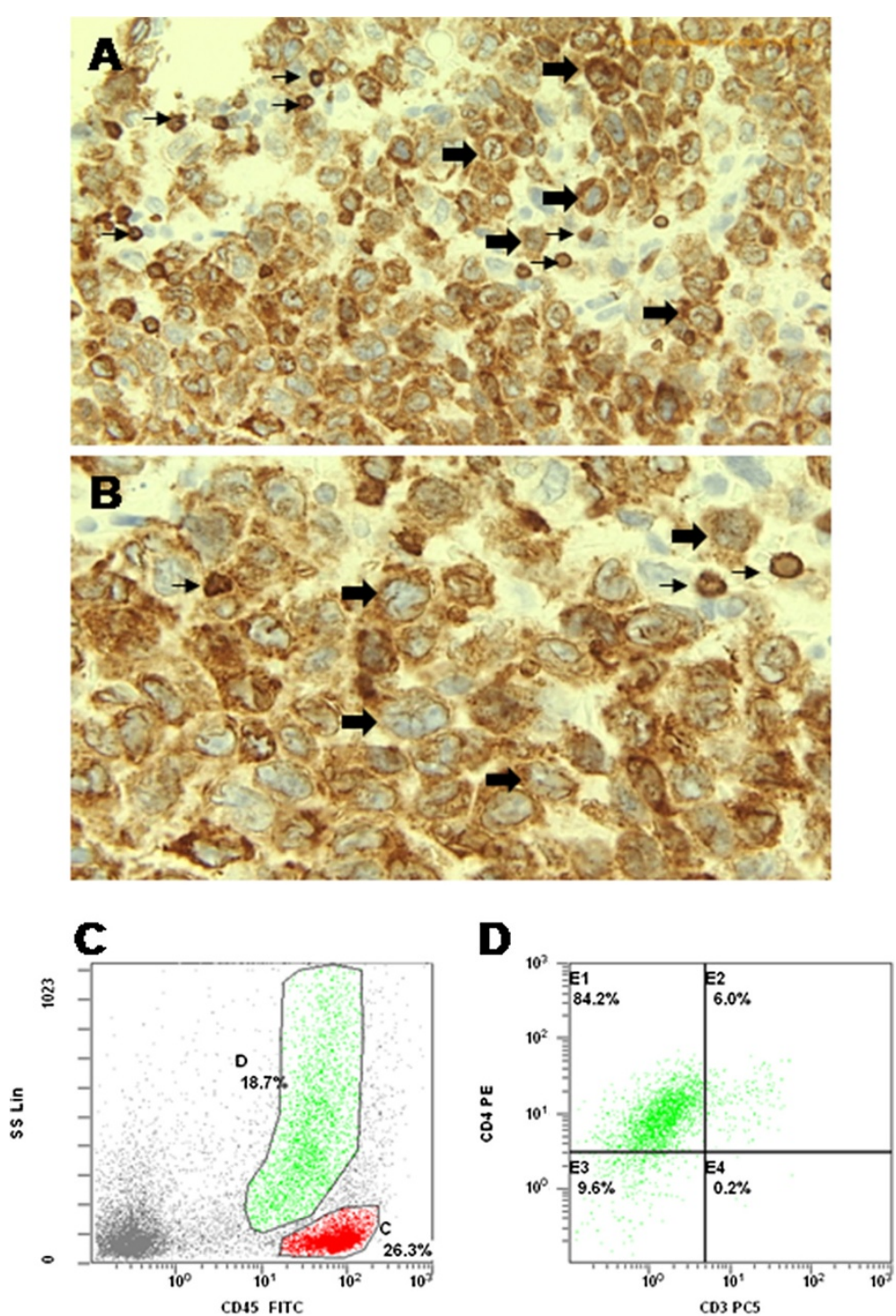

Figure 2 T cell specific marker CD3 staining and Lymph node flow cytometry. A. Low power view and B. high power view showing tumor cells had focal cytoplasmic CD3 staining (large arrows) in contrast to background small T lymphocytes with strong membrane CD3 staining (small arrows). C, D. Lymph node flow cytometry immunophenotyping showed 2 populations of cells, with normal lymphocytes (in red) and an abnormal population with high side scatter (in green) which show expression of CD4 and are negative for surface CD3. Cytoplasm CD3 was not done.

In our case, because of the expression of cytoplasmic CD3 and CD4, we performed T cell receptor (TCR) gene arrangement studies for gamma, delta and beta chains by PCR to rule out the possibility of T cell lineage transdifferentiation or lineage plasticity. The results failed to demonstrate a clonal rearrangement pattern, suggesting that the LCS tumor cells had an aberrant cytoplasmic CD3 expression rather than a $\mathrm{T}$ cell transdifferentiation phenomenon.

As a rare subtype of sarcoma, LCS has a poor prognosis [30]. Although the prognostic factors in LCS were not known, they might include prognostic factors common to other rare sarcomas, such as patient age, tumor size, tumor cell grade, proliferation rate, and/or stage. [31-33]. DNA ploidy had been proposed as one of the prognostic factors in some subtypes of sarcoma $[31,34]$, although another study does not show ploidy status to be an independent prognostic factor [35]. The prognostic role of DNA ploidy in LCS had never been explored. In our case, due to the rarity of LCS and finesse of the technique, DNA ploidy study was not performed.

Among the reported LCS cases [1], patients had a predominantly female distribution with a median age of 
39 years old, ages ranging from 10 to 72 years. Our patient, at 86 was thus the oldest reported to date.

\section{Conclusion}

In summary, we reported the first case of Langerhans cell sarcoma with an aberrant cytoplasmic CD3 expression, which initially with insufficient immunophenotyping created diagnostic difficulty, especially about lineage assignment. Recognizing the cytomorphologic features characteristic of Langerhans cells prompted use of markers enabling the correct diagnosis.

\section{Consent}

Written informed consent was obtained from the patient for publication of this Case Report and any accompanying images. A copy of the written consent is available for review by the Editor-in-Chief of this journal.

\section{Competing interests}

The authors declare that they have no competing interests.

\section{Authors' contributions}

The manuscript was prepared by ZX under the supervision of BFB. BFB and ZX were directly involved in diagnosis and interpretation of histology and immunohistochemistry results. RP were responsible for interpretation of flow cytometry results and paper discussion. CF and LD were responsible for the treatment of the patient. All authors read and approved the final manuscript.

\section{Author details}

${ }^{1}$ Department of Pathology and Laboratory Medicine, Division of Hematopathology, The Ottawa Hospital, 501 Smyth Road, Ottawa, Ontario, Canada. ${ }^{2}$ Department of Medicine, Division of Hematology, The Ottawa Hospital, 501 Smyth Road, Ottawa, Ontario, Canada. ${ }^{3}$ Department of Pathology and Laboratory Medicine, Division of Anatomical Pathology, The Ottawa Hospital, 501 Smyth Road, Ottawa, Ontario, Canada.

Received: 10 July 2012 Accepted: 23 September 2012

Published: 25 September 2012

\section{References}

1. Swerdlow SH, Campo E, Harris NL, Jaffe ES, Pileri SA, Stein H, Thiele J, Vardiman JW: WHO classification of tumors of haematopoietic and lymphoid tissues. France: International Agency for Research on Cancer; 2008.

2. Chikwava K, Jaffe R: Langerin (CD207) staining in normal pediatric tissues, reactive lymph nodes, and childhood histiocytic disorders. Pediatr Dev Pathol 2004, 7:607-614.

3. Krenács L, Tiszalvicz L, Krenács T, Boumsell L: Immunohistochemical detection of CD1A antigen in formalin-fixed and paraffin-embedded tissue sections with monoclonal antibody 010. J Pathol 1993, 171:99-104.

4. Pileri SA, Gaidano G, Zinzani PL, Pileri SA, Grogan TM, Harris NL, Banks P, Campo E, Chan JK, Favera RD, Delsol G, De Wolf-Peeters C, Falini B, Gascoyne RD, Gaulard P, Gatter KC, Isaacson PG, Jaffe ES, Kluin P, Knowles DM, Mason DY, Mori S, Müller-Hermelink HK, Piris MA, Ralfkiaer E, Stein H, Su IJ, Warnke RA, Weiss LM: Tumours of histiocytes and accessory dendritic cells: an immunohistochemical approach to classification from the International Lymphoma Study Group based on 61 cases. Histopathology 2002, 41:1-29

5. Uchida K, Kobayashi S, Inukai T, Noriki S, Imamura Y, Nakajima H, Yayama T, Orwotho N, Baba H: Langerhans cell sarcoma emanating from the upper arm skin: successful treatment by MAID regimen. J Orthop Sci 2008, 13:89-93.

6. Forero-Torres A, Leonard JP, Younes A, Rosenblatt JD, Brice P, Bartlett NL, Bosly A, Pinter-Brown L, Kennedy D, Sievers EL, Gopal AK: A Phase II study of SGN-30 (anti-CD30 mAb) in Hodgkin lymphoma or systemic anaplastic large cell lymphoma. Br J Haematol 2009, 146:171-179.
7. Oken MM, Creech RH, Tormey DC, Horton J, Davis TE, McFadden ET, Carbone PP: Toxicity And Response Criteria Of The Eastern Cooperative Oncology Group. Am J Clin Oncol 1982, 5:649-655.

8. Dacic S, Trusky C, Bakker A, Finkelstein SD, Yousem SA: Genotypic analysis of pulmonary Langerhans cell histiocytosis. Hum Pathol 2003, 34:1345-1349.

9. Yousem SA, Colby TV, Chen YY, Chen WG, Weiss LM: Pulmonary Langerhans' cell histiocytosis: molecular analysis of clonality. Am J Surg Pathol 2001, 25:630-636.

10. Bramwell $\mathrm{NH}$, Burns BF: Histiocytosis $\mathrm{X}$ of the thymus in association with myasthenia gravis. Am J Clin Pathol 1986, 86:224-227.

11. Burns BF, Colby TV, Dorfman RF: Langerhans' cell granulomatosis (histiocytosis X) associated with malignant lymphomas. Am J Surg Pathol 1983, 7:529-533.

12. Merad M, Ginhoux F, Collin M: Origin, homeostasis and function of Langerhans cells and other langerin-expressing dendritic cells. Nat Rev Immunol 2008, 8:935-947.

13. Geissmann F, Prost C, Monnet JP, Dy M, Brousse N, Hermine O: Transforming growth factor beta1, in the presence of granulocyte / macrophage colony-stimulating factor and interleukin 4, induces differentiation of human peripheral blood monocytes into dendritic Langerhans cells. J Exp Med 1998, 187:961-966.

14. Hoshino N, Katayama N, Shibasaki T, Ohishi K, Nishioka J, Masuya M, Miyahara Y, Hayashida M, Shimomura D, Kato T, Nakatani K, Nishii K, Kuribayashi K, Nobori T, Shiku H: A novel role for Notch ligand Delta-1 as a regulator of human Langerhans cell development from blood monocytes. J Leukoc Biol 2005, 78:921-929.

15. Egeler RM, van Halteren AG, Hogendoorn PC, Laman JD, Leenen PJ: Langerhans cell histiocytosis: fascinating dynamics of the dendritic cellmacrophage lineage. Immunol Rev 2010, 234:213-232.

16. Rasaiyaah J, Yong K, Katz DR, Kellam P, Chain BM: Dendritic cells and myeloid leukaemias: plasticity and commitment in cell differentiation. $\mathrm{Br}$ J Haematol 2007, 138:281-290.

17. Anjuère F, del Hoyo GM, Martín P, Ardavín C: Langerhans cells develop from a lymphoid-committed precursor. Blood 2000, 96:1633-1637.

18. Chen W, Wang J, Wang E, Lu Y, Lau SK, Weiss LM, Huang Q: Detection of clonal lymphoid receptor gene rearrangements in langerhans cell histiocytosis. Am J Surg Pathol 2010, 34:1049-1057.

19. Feldman AL, Berthold F, Arceci RJ, Abramowsky C, Shehata BM, Mann KP, Lauer SJ, Pritchard J, Raffeld M, Jaffe ES: Clonal relationship between precursor T-lymphoblastic leukaemia/lymphoma and Langerhans-cell histiocytosis. Lancet Oncol 2005, 6:435-437.

20. Feldman AL, Arber DA, Pittaluga S, Martinez A, Burke JS, Raffeld M, Camos M, Warnke R, Jaffe ES: Clonally related follicular lymphomas and histiocytic/dendritic cell sarcomas: evidence for transdifferentiation of the follicular lymphoma clone. Blood 2008, 111:5433-5439.

21. Shao H, Xi L, Raffeld M, Feldman AL, Ketterling RP, Knudson R, RodriguezCanales J, Hanson J, Pittaluga S, Jaffe ES: Clonally related histiocytic/ dendritic cell sarcoma and chronic lymphocytic leukemia/small lymphocytic lymphoma: a study of seven cases. Mod Pathol 2011, 24:1421-1432.

22. Ratei $R$, Hummel $M$, Anagnostopoulos I, Jähne $D$, Arnold R, Dörken $B$, Mathas S, Benter T, Dudeck O, Ludwig WD, Stein H: Common clonal origin of an acute B-lymphoblastic leukemia and a Langerhans' cell sarcoma: evidence for hematopoietic plasticity. Haematologica 2010, 95:1461-1466.

23. Feldman AL: Langerhans cell sarcoma, clonally related to the original follicular lymphoma, so called "Transdifferentiation" of the follicular lymphoma clone. In USCAP 2010 hematopathology specialty conference handout.

24. Sun J, Medeiros LJ, Lin P, Lu G, Bueso-Ramos CE, You MJ: Plasmablastic lymphoma involving the penis: a previously unreported location of a case with aberrant CD3 expression. Pathology 2011, 43:54-57.

25. Wang E, Stoecker M: Primary mediastinal (thymic) large B cell lymphoma with aberrant expression of CD3: a case report with review of the literature. Int J Hematol 2010, 91:509-515.

26. Wallentine JC, Perkins SL, Tripp SR, Bruggman RD, Bayerl MG: Diffuse large B-cell lymphoma with coexpression of CD3 in a pediatric patient: a case report, review of the literature, and tissue microarray study. J Pediatr Hematol Oncol 2009, 31:124-127.

27. Tzankov A, Bourgau C, Kaiser A, Zimpfer A, Maurer R, Pileri SA, Went P, Dirnhofer S: Rare expression of T-cell markers in classical Hodgkin's lymphoma. Mod Pathol 2005, 18:1542-1549. 
28. Li S, Borowitz MJ: CD79a + T-cell lymphoblastic lymphoma with coexisting Langerhans cell histiocytosis. Arch Pathol Lab Med 2001, 125:958-960.

29. Ko YH, Kim WS, Kim Y: Expression of CD56 antigen in Langerhans cell histiocytosis associated with T-lymphoblastic lymphoma in a same lymph node. Virchovs Archiv 2006, 448:90-94.

30. Kawase T, Hamazaki M, Ogura M, Kawase Y, Murayama T, Mori Y, Nagai H, Tateno M, Oyama T, Kamiya Y, Taji H, Kagami Y, Naoe T, Takahashi T, Morishima Y, Nakamura S: CD56/NCAM-positive Langerhans cell sarcoma: a clinicopathologic study of 4 cases. Int J Haematol. 2005, 81:323-329.

31. Balogh Z, Szemlaky Z, Szendroi M, Antal I, Pápai Z, Fónyad L, Papp G, Changchien YC, Sápi Z: Correlation between DNA ploidy, metaphase high-resolution comparative genomic hybridization results and clinical outcome of synovial sarcoma. Diagn Pathol 2011, 6:107-114.

32. Babarović E, Zamolo G, Mustać E, Strčić M: High grade angiosarcoma arising in fibroadenoma. Diagn Pathol 2011, 6:125-130.

33. Bösmüller H, Gruber $C$, Haitchi-Petnehazy $S$, Wagner D, Webersinke $G$, Hauptmann S: Primary angiosarcoma of the ovary with prominent fibrosis of the ovarian stroma. Case report of an 81-year old patient. Diagn Pathol 2011, 6:65-71.

34. Mertens F, Stromberg U, Mandahl N, Dal Cin P, de Wever I, Fletcher CD, Mitelman F, Rosai J, Rydholm A, Sciot R, Tallini G, van den Berghe H, Vanni $\mathrm{R}$, Willen $\mathrm{H}$ : Prognostically important chromosomal aberrations in soft tissue sarcomas: a report of the Chromosomes and Morphology (CHAMP) study group. Cancer Res 2002, 62:3980-3984.

35. Dreinhofer KE, Baldetorp B, Akerman M, Ferno M, Rydholm A, Gustofson P: DNA ploidy in soft tissue sarcoma: comparison of flow and image cytometry with clinical follow-up in 93 patients. Cytometry 2002, 50:19-24.

doi:10.1186/1746-1596-7-128

Cite this article as: Xu et al.: Langerhans cell sarcoma with an aberrant cytoplasmic CD3 expression. Diagnostic Pathology 2012 7:128.

\section{Submit your next manuscript to BioMed Central and take full advantage of:}

- Convenient online submission

- Thorough peer review

- No space constraints or color figure charges

- Immediate publication on acceptance

- Inclusion in PubMed, CAS, Scopus and Google Scholar

- Research which is freely available for redistribution

Submit your manuscript at www.biomedcentral.com/submit
() Biomed Central 